\title{
ANALISIS DEFORMASI LATERAL GRUP PONDASI TIANG DENGAN PERKUATAN MENGGUNAKAN TIANG MIRING (BATTER PILES) PADA JEMBATAN DERMAGA
}

\author{
Wirman Hidayat \\ Program Studi Teknik Sipil, Universitas Pertamina \\ Email: wirman.hidayat@universitaspertamina.ac.id
}

\begin{abstract}
ABSTRAK: Deformasi lateral pada grup pondasi tiang merupakan salah satu parameter yang harus diperhatikan dengan baik, karena deformasi lateral yang besar dapat menyebabkan kerusakan pada struktur. Perkuatan menggunakan tiang miring (batter piles) merupakan salah satu metode yang dapat digunakan dalam meningkatkan tahanan lateral grup pondasi tiang. Penggunaan batter piles secara mekanis menyalurkan beban horizontal kepada daya dukung pondasi vertikal, sehingga beban lateral yang harus ditahan pondasi terdistribusi menjadi komponen vertikal dan horizontal. Penelitian ini bertujuan untuk menganalisis deformasi lateral grup pondasi tiang pada jembatan dermaga yang mengalami deformasi yang cukup besar berdasarkan data hasil pengukuran, kemudian dilakukan perancangan perkuatan menggunakan batter piles untuk meningkatkan tahanan lateral. Analisis dilakukan menggunakan perangkat lunak PLAXIS 2D dan GROUP7. Dari hasil analisis diperoleh bahwa perkuatan menggunakan batter piles dapat mengurangi deformasi lateral yang terjadi pada jembatan, berdasarkan analisis menggunakan PLAXIS 2D diperoleh pengurangan deformasi lateral sebesar $57 \%$ atau sebesar $2.89 \mathrm{~cm}$, sedangkan berdasarkan hasil analisis menggunakan GROUP7 diperoleh pengurangan deformasi lateral sebesar $76 \%$ atau berkurang sebesar $3.88 \mathrm{~cm}$ dibandingkan dengan deformasi hasil pengukuran pada jembatan tanpa menggunakan batter piles. Hasil analisis menunjukkan bahwa penggunaan batter piles pada pondasi jembatan dermaga mampu mengurangi deformasi lateral dengan efektif dan meningkatkan stabilitas geoteknik.
\end{abstract}

Kata Kunci: batter piles, deformasi lateral, tahanan lateral

\section{LATERAL DEFORMATION ANALYSIS OF GROUP PILES FOUNDATION REINFORCEMENT USING BATTER PILES ON THE JETTY BRIDGE}

\begin{abstract}
Lateral deformation of group pile foundation is one parameter that must be considered properly, because excessive lateral deformations can cause damage to the structure. Reinforcement using inclined piles (batter piles) can be used to increase the lateral resistance of the group piles foundation. The use of batter piles mechanically distributes the horizontal loads to the vertical foundation bearing capacity, so that the lateral load which carried by the foundation is distributed into vertical and horizontal components, to reduce the lateral deformation that occurs. In this study, the lateral deformation analysis was carried out on the group piles foundation on the jetty bridge which experienced a large deformation, then the reinforcement design was designed using batter piles to increase lateral resistance. The analysis was performed using PLAXIS 2D and GROUP7 software. From the analysis, it was found that reinforcement using batter piles can reduce the lateral deformation that occurs, based on the analysis using PLAXIS 2D a reduction in lateral deformation was obtained by $57 \%$ or $2.89 \mathrm{~cm}$, whereas based on the results of the analysis using GROUP7, the percentage of deformation reduction was $76 \%$ or decreased by $3.88 \mathrm{~cm}$ against the deformation of the monitoring result. The analysis results show that the use of batter piles on the foundation of the pier bridge can reduce lateral deformation effectively and improve geotechnical stability.
\end{abstract}

Keywords: batter piles, lateral deformation, lateral resistance 


\section{PENDAHULUAN}

Penggunaan pondasi tiang merupakan praktek yang lazim dalam menyalurkan beban struktur dengan baik ke lapisan tanah yang terdapat dibawahnya, terutama untuk struktur yang memiliki beban yang besar. Pada beberapa jenis struktur bekerja beban horizontal yang cukup besar yang diakibatkan oleh beban operasional, salah satunya adalah struktur jembatan dermaga. Batter piles merupakan pondasi tiang yang dipasang dengan kemiringan tertentu dengan tujuan untuk memberikan tahanan horizontal, sehingga dapat meningkatkan stabilitas struktur dan mengurangi deformasi lateral yang terjadi. Penggunaan batter piles dalam studi kasus dan penelitian menunjukan bahwa hasil penggunaan batter piles dapat meningkatkan daya dukung pondasi, mengurangi deformasi pada pondasi, dan mengurangi momen yang terjadi pada pondasi (Shahrour, et al., 2012; Zhe \& Dong, 2014; Chen \& Hsu, 2017; Han, et al., 2021)

Defomasi lateral yang besar dapat menimbulkan kerugian dari sisi operasional dan dapat menyebabkan kerusakan pada struktur, sehingga diperlukan perencanaan yang baik dalam proses konstruksi yang dilakukan. Pada beberapa kasus terdapat kondisi dimana terjadi deformasi lateral yang signifikan setelah proses konstruksi selesai yang disebabkan oleh daya dukung pondasi secara lateral tidak mampu menahan beban yang bekerja, sehingga perlu dilakukan perkuatan pada struktur untuk meningkatkan daya dukung pondasi secara lateral.

Penelitian ini bertujuan untuk menganalisis deformasi lateral grup pondasi tiang menggunakan batter piles dengan studi kasus pada jembatan dermaga sungai yang berlokasi di Kalimantan Tengah. Pada kasus yang ditinjau, terdapat jembatan dermaga dengan panjang 94.5 meter dan lebar 12.5 meter yang digunakan sebagai penghubung antara dermaga dengan area darat. Pada perancangan awal, jembatan disangga oleh struktur pondasi tiang menggunakan PC Spun Pile yang dipasang secara vertikal dengan diameter pondasi 600 $\mathrm{mm}$, pondasi tiang disusun dengan konfigurasi persegi, jarak antar pondasi adalah 3.5 meter dan kedalaman pemasangan pondasi adalah 40 meter. Setelah proses konstruksi selesai, dilakukan proses monitoring deformasi lateral pada jembatan. Ditemukan bahwa jembatan mengalami deformasi lateral yang cukup siginifikan, yaitu sebesar $5.10 \mathrm{~cm}$. Berkaitan dengan kondisi deformasi lateral yang dinilai cukup besar, maka diperlukan perkuatan pada jembatan untuk mengurangi deformasi lateral tersebut. Penggunaan batter piles merupakan metode perkuatan yang direncanakan sebagai perkuatan dalam meningkatkan kemampuan pondasi dalam menahan beban lateral pada kasus ini. Penelitian ini dilakukan menggunakan perangkat lunak berbasis metode elemen hingga yaitu PLAXIS 2D dan metode beda hingga nonlinear yaitu GROUP7, penggunaan 2 (dua) perangkat lunak yang berbeda bertujuan untuk menganalisis pendekatan terbaik yang mendekati hasil pengukuran dilapangan.

\section{MATERI DAN METODE \\ Deformasi Lateral Pondasi}

Perhitungan terhadap deformasi lateral pada pondasi tiang merupakan salah satu aspek penting dalam perencanaan dan analisis pondasi. Salah satu metode perhitungan yang biasa dilakukan adalah dengan menggunakan kurva py yang dapat memprediksi sifat non-linear pada deformasi lateral pondasi. Kurva ini terdiri dari parameter $\mathbf{p}$ yang merupakan tahanan lateral yang bekerja pada pondasi dan parameter $\mathbf{y}$ yang merupakan deformasi lateral pondasi. Studi tentang kurva p-y dilakukan oleh Matlock (1970) dan Sullivan et al. (1980), dari studi yang dilakukan tersebut diperoleh bahwa hasil perhitungan kurva p-y mampu memodelkan sifat non-linear tahanan dan deformasi lateral terhadap kedalaman, akan tetapi, model ini mempunyai keterbatasan dalam memperhitungkan interaksi antara tanah dan pondasi.

Dengan perkembangan teknologi komputasi, analisis deformasi lateral pondasi menggunakan bantuan komputer dan perangkat lunak semakin banyak dilakukan. Hal ini memberikan keuntungan dari segi kemudahan pengerjaan, peningkatan ketelitian, waktu perhitungan yang lebih singkat, dan penghematan biaya. Isenhower \& Wang (2014) melakukan pengembangan terhadap program komputer untuk menghitung deformasi lateral pondasi menggunakan metode p-y yang digunakan dalam perangkat lunak GROUP7. Program ini mampu membuat pemodelan yang kompleks dan memberikan output yang lebih banyak, yaitu deformasi, momen, tegangan geser, modulus tanah dan pondasi tiang, serta tahanan lateral tanah. 
Tahanan Lateral Tiang Miring (Batter Piles)

Tiang miring atau batter piles merupakan pondasi tiang yang dipasang terhadap sudut tertentu dari arah vertikal. Penggunaan tiang ini biasanya digunakan apabila beban lateral yang harus ditahan pondasi cukup besar sehingga kekakuan struktur perlu ditingkatkan. Willson et al. (2006) menjelaskan bahwa batter piles secara mekanis menyalurkan beban horizontal kepada daya dukung pondasi vertikal, sehingga beban lateral yang harus ditahan pondasi akan berkurang.

Xie et al. (2017) melakukan penelitan terhadap perilaku batter piles terhadap beban lateral menggunakan perangkat lunak komputer berbasis elemen hingga. Parameter yang digunakan dalam analisis ini adalah faktor kemiringan tiang, ukuran tiang, dan besar beban horizontal yang bekerja pada tiang. Dari analisis tersebut diperoleh hasil bahwa metode elemen hingga mempunyai hasil yang cukup akurat dalam memprediksi deformasi yang terjadi pada batter piles. Penelitian tentang tahanan lateral batter piles secara non-linear juga dilakukan oleh Ashour et al. (2019) dengan menganalisis pengaruh beban terhadap deformasi lateral berdasarkan kedalaman tanah dan dibandingkan dengan hasil pengukuran pada model yang dibuat menggunakan prinsip sentrifugal, dimana diperoleh bahwa permodelan secara non-linear memberikan hasil yang mendekati kondisi pemodelan batter piles dengan prinsip sentrifugal.

\section{Model Konstitutif Tanah Hardening Soil}

Model tanah hardening soil merupakan salah satu model konstitutif yang digunakan dalam perangkat lunak berbasis elemen hingga PLAXIS 2D. Model ini merupakan salah satu model tanah yang memiliki pendekatan yang baik terhadap analisis deformasi. Pada dasarnya model ini merupakan model tingkat lanjut dengan membedakan 2 (dua) tipe pembebanan yaitu pembebanan geser (shear hardening) dan pembebanan tekan (compression hardening). Shear hardening digunakan dalam perhitungan deformasi lateral plastis akibat pembebanan deviatorik, sedangkan compression hardening digunakan dalam perhitungan pembebanan tekan pada oedometer yang bersifat isotropic. Deformasi lateral plastis yang dihasilkan pada 2 (dua) tipe pembebanan tersebut bersifat tidak dapat pulih (irreversible) Brinkgreve (2015).

Untuk melakukan analisis deformasi lateral grup pondasi tiang dengan perkuatan menggunakan batter piles pada jembatan dermaga, maka disusun langkah-langkah dalam melakukan penelitian, diagram alir penelitian ini terdapat pada gambar Gambar 1.

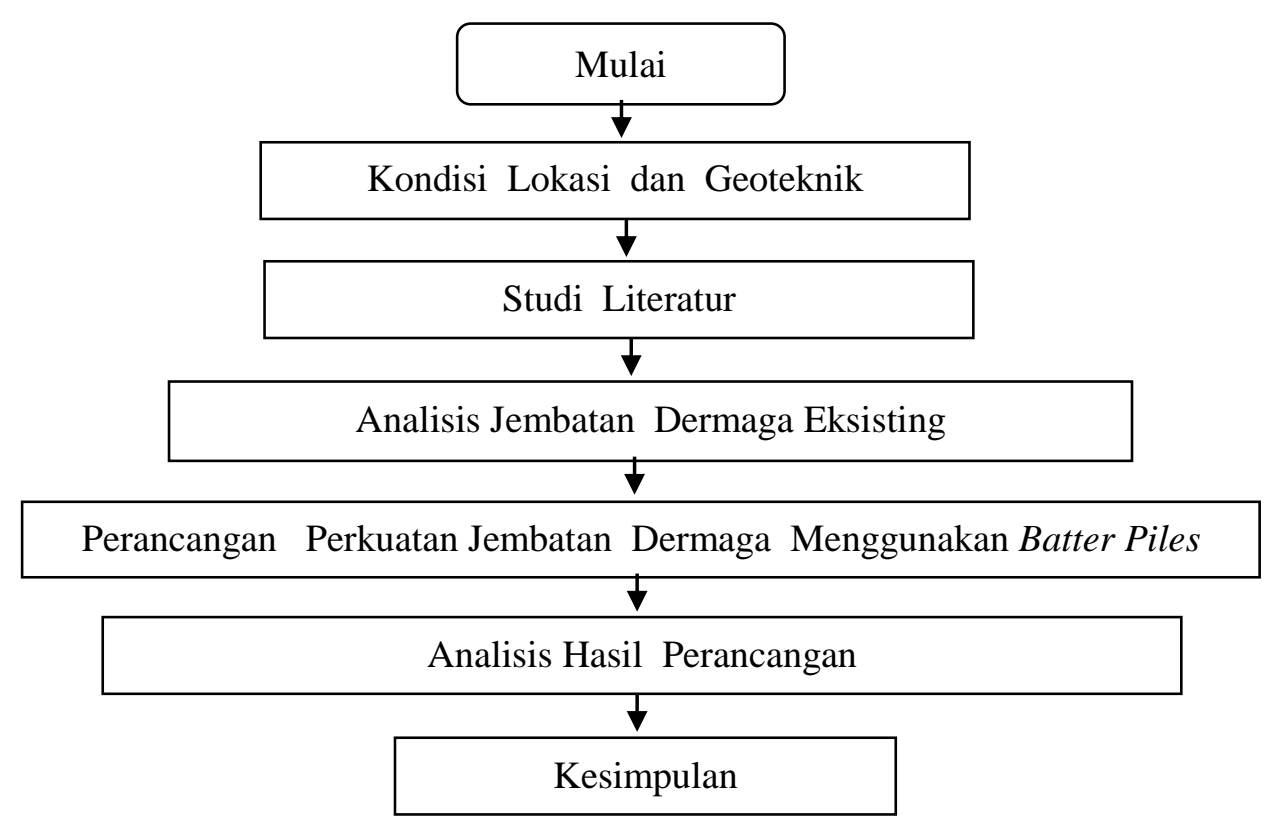

Gambar 1. Diagram Alir Penelitian 


\section{HASIL DAN PEMBAHASAN}

Kondisi Lokasi Dan Geoteknik

Lokasi studi kasus yang ditinjau terletak di Provinsi Kalimantan Tengah, kondisi kontur tanah di sekitar sungai relatif landai dan didominasi oleh lapisan tanah lunak pada lapisan paling atas. Berdasarkan hasil penyelidikan tanah yang dilakukan, diperoleh hasil berupa data tanah, kondisi muka air, dan kontur permukaan tanah. Penyelidikan tanah yang dilakukan meliputi pengeboran tanah, pengujian Standard Penetration Test (SPT), pengujian Triaxial Unconsolidated-Undrained (UU), dan pengujian geser langsung (direct shear). Berdasarkan hasil pengeboran tanah dan pengujian SPT, diperoleh profil tanah terhadap kedalaman yang terdapat pada Tabel 1, dimana terdapat lapisan tanah lempung sangat lunak pada bagian lapisan atas dengan ketebalan 16 meter, kemudian pada lapisan kedua terdapat lapisan tanah lempung lunak dengan ketebalan 11 meter, dan pada lapisan paling bawah ditemukan tanah berjenis pasir sangat padat sampai dengan kedalaman 42 meter. Kedalaman dasar sungai bervariasi dari 2 meter sampai dengan 10 meter dibawah permukaan air sungai rata-rata.

Berdasarkan hasil pengujian SPT juga diperoleh parameter tanah yang digunakan dalam analisis, yaitu berat volume tanah $(\gamma)$, poisson's ratio $(v)$, dan koefisien permeabilitas (k) yang ditentukan melalui korelasi empirik hasil pengujian SPT, sedangkan parameter kekuatan tanah (c' dan $\phi ')$ dan modulus tanah (E') diperoleh dari hasil pengujian triaxial UU dan direct shear. Parameter tanah untuk masingmasing lapisan tanah terdapat pada Tabel. 2.

\section{Model Analisis}

Penelitian ini dilakukan menggunakan perangkat lunak PLAXIS 2D dimana perangkat lunak ini memiliki dasar perhitungan menggunakan Metode Elemen Hingga (MEH). Metode ini biasa digunakan untuk melakukan analisis stabilitas dan deformasi. Kemudian juga digunakan perangkat lunak GROUP7 yang merupakan perangkat lunak yang secara spesifik memiliki kegunaan untuk analisis grup pondasi, GROUP7 memiliki dasar perhitungan menggunakan Metode Beda Hingga Nonlinear pada tanah, sehingga bisa memberikan luaran berupa deformasi lateral, gaya, dan momen. Penggunaan GROUP7 relatif lebih sederhana dibandingkan dengan penggunaan PLAXIS 2D, ditinjau dari segi model input, langkah pemodelan dan waktu yang dibutuhkan untuk analisis.

Tabel 1. Profil Lapisan Tanah

\begin{tabular}{lccc}
\hline Kedalaman $(\mathrm{m})$ & Jenis Tanah & Model Material & Jenis Drainasi \\
\hline Lapisan 1 (0 s/d 16) & Lempung & Hardening Soil & Undrained \\
Lupisan 2 (>16 s/d 27) & Lempung & Hardening Soil & Undrained \\
Lunak 2 & Hardening Soil & Drained \\
\hline
\end{tabular}

Tabel. 2 Parameter Tanah

\begin{tabular}{|c|c|c|c|c|c|c|c|c|}
\hline \multirow{3}{*}{ Kedalaman (m) } & \multirow{3}{*}{$\begin{array}{l}\gamma_{\text {dry }} / \gamma_{\text {sat }} \\
\left(\mathrm{kN} / \mathrm{m}^{3}\right)\end{array}$} & \multirow{3}{*}{$\begin{array}{l}\text { Poisson's } \\
\text { Ratio }\end{array}$} & \multirow{3}{*}{$\begin{array}{l}\text { Koef Permeabiltas } \\
\text { (cm/detik) }\end{array}$} & \multirow{2}{*}{\multicolumn{2}{|c|}{$\begin{array}{l}\text { Parameter } \\
\text { Kekuatan }\end{array}$}} & \multirow{2}{*}{\multicolumn{3}{|c|}{ Modulus (kPa) }} \\
\hline & & & & & & & & \\
\hline & & & & $\mathrm{c}(\mathrm{kPa})$ & $\phi\left(^{\circ}\right)$ & $E^{\prime}\left(E_{50}\right)$ & $\mathrm{E}_{\mathrm{oed}}$ & $\mathrm{E}_{\mathrm{ur}}$ \\
\hline Lapisan $1(0-16)$ & $15.3 / 16.4$ & 0.40 & $2.4 \times 10^{-8}$ & 6 & 0 & 1950 & 1560 & 4680 \\
\hline Lapisan $2(>16-27)$ & $15.7 / 16.8$ & 0.35 & $2.1 \times 10^{-8}$ & 8 & 0 & 2600 & 2080 & 7800 \\
\hline Lapisan $3(>27-42)$ & $16.4 / 17.6$ & 0.30 & $4.7 \times 10^{-4}$ & 2 & 32 & 15000 & 12000 & 45000 \\
\hline
\end{tabular}




\section{Model Analisis Jembatan Dermaga Eksisting}

Pada tahap pertama pemodelan dilakukan analisis deformasi lateral pada jembatan dermaga eksisting menggunakan perangkat lunak. Dalam hal ini jembatan sudah selesai dikonstruksi dengan konfigurasi geometri struktur dan pemasangan pondasi seperti pada Gambar 2 dan Gambar 3. Berdasarkan data tersebut dibuat model geometri menggunakan PLAXIS 2D dan GROUP7. Analisis ini bertujuan untuk menghitung deformasi lateral jembatan eksisting. Hasil analisis dibandingkan dengan hasil pengukuran di lapangan, sehingga model yang dibuat dapat diverifikasi dengan baik. Pada PLAXIS 2D struktur pondasi dibuat dengan elemen embedded beam dengan jenis material pondasi adalah beton PC Spun Piles berdiameter $600 \mathrm{~mm}$ Class A2 (PC Spun Pile D600). Untuk lantai jembatan dimodelkan dengan elemen pelat (plate) dengan jenis material beton yang memiliki ketebalan $30 \mathrm{~cm}$. Untuk pemodelan struktur pada perangkat lunak GROUP7, pondasi dimodelkan dengan elemen pile dan lantai jembatan dimodelkan dengan pile cap. Beban yang digunakan dalam analisis merupakan beban vertikal dan horizontal yang terjadi pada kondisi operasional jembatan, berikut adalah beban yang bekerja pada jembatan:

Tabel 3. Beban Operasional Pada Jembatan Dermaga

\begin{tabular}{clc}
\hline No & Deskripsi Beban & Besar Beban \\
\hline 1 & Beban Vertikal & $30 \mathrm{kPa}$ \\
2 & Beban Horizontal & $65.5 \mathrm{kN}$ \\
\hline
\end{tabular}

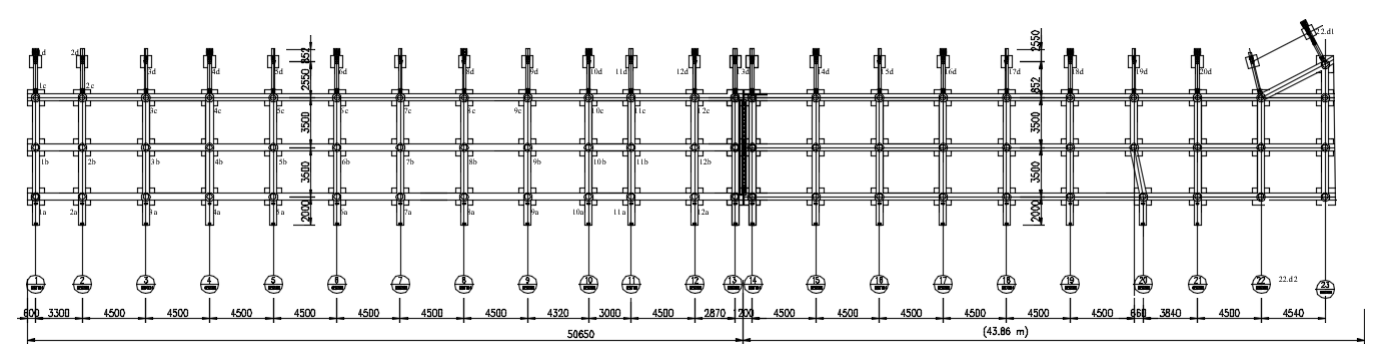

Gambar 2. Tampak Atas Jembatan Dermaga Eksisting

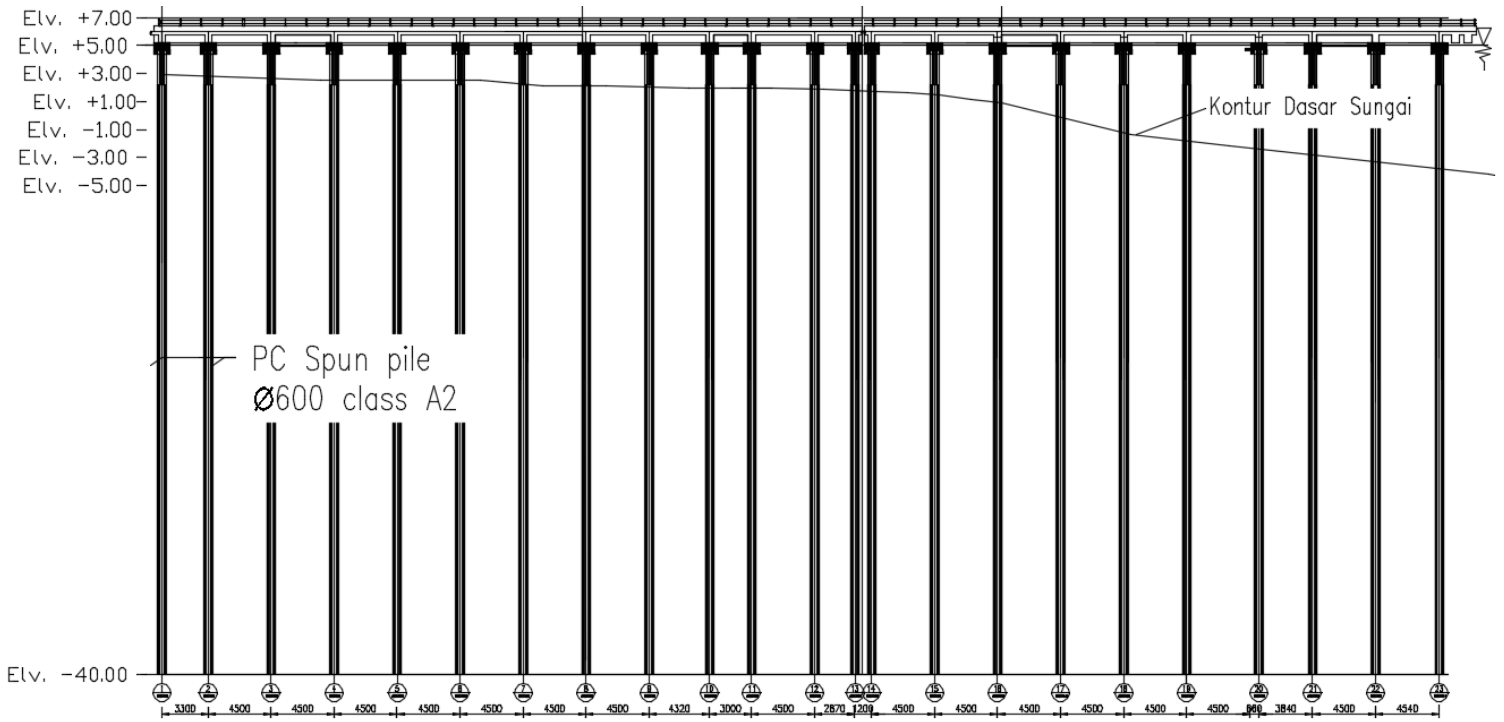

Gambar 3. Potongan Memanjang Jembatan Dermaga Eksisting 


\section{Model Perancangan Perkuatan Jembatan Menggunakan Batter Piles}

Dalam perancangan perkuatan menggunakan batter piles, digunakan penambahan pondasi berjenis steel pipe dengan diameter luar (OD) $500 \mathrm{~mm}$ (Steel Pipe OD500), ketebalan $10 \mathrm{~mm}$. Pondasi ini dipasang sampai kedalaman 39 meter, sehingga pondasi terpasang sampai dengan kedalaman tanah keras. Konfigurasi pemasangan batter piles, tampak atas, dan potongan memanjang jembatan dapat dilihat pada Gambar 4 dan Gambar 5, konfigurasi pemasangan batter piles adalah berbentuk persegi, menggunakan 4 tiang pada setiap satu grup pondasi. Total jumlah batter piles yang digunakan pada perkuatan adalah sebanyak 16 tiang, sudut pemasangan batter piles terhadap vertikal adalah $-12,7^{\circ}$ dan $+12,7^{\circ}$. Pada perangkat lunak PLAXIS 2D dan GROUP7 dibuat model sesuai dengan perancangan perkuatan menggunakan batter piles seperti pada Gambar 6

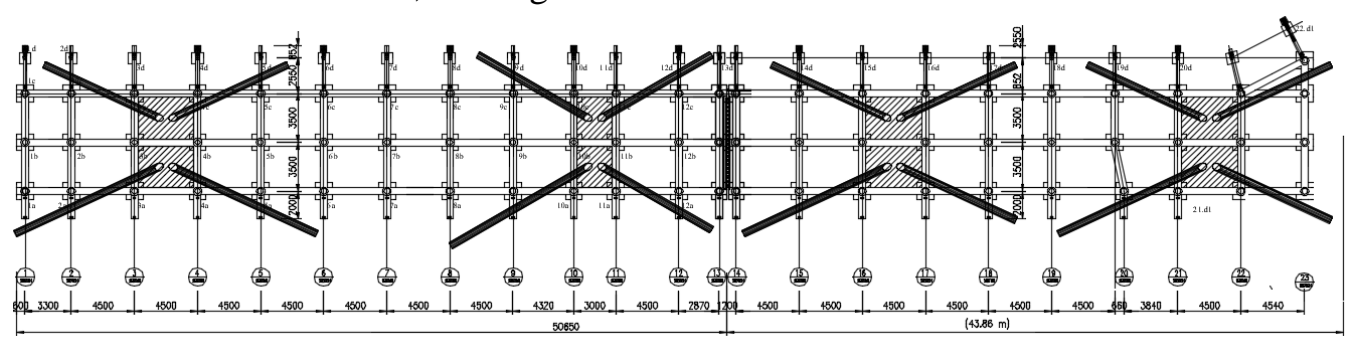

Gambar 4. Tampak Atas Pemasangan Batter Piles Pada Jembatan Dermaga

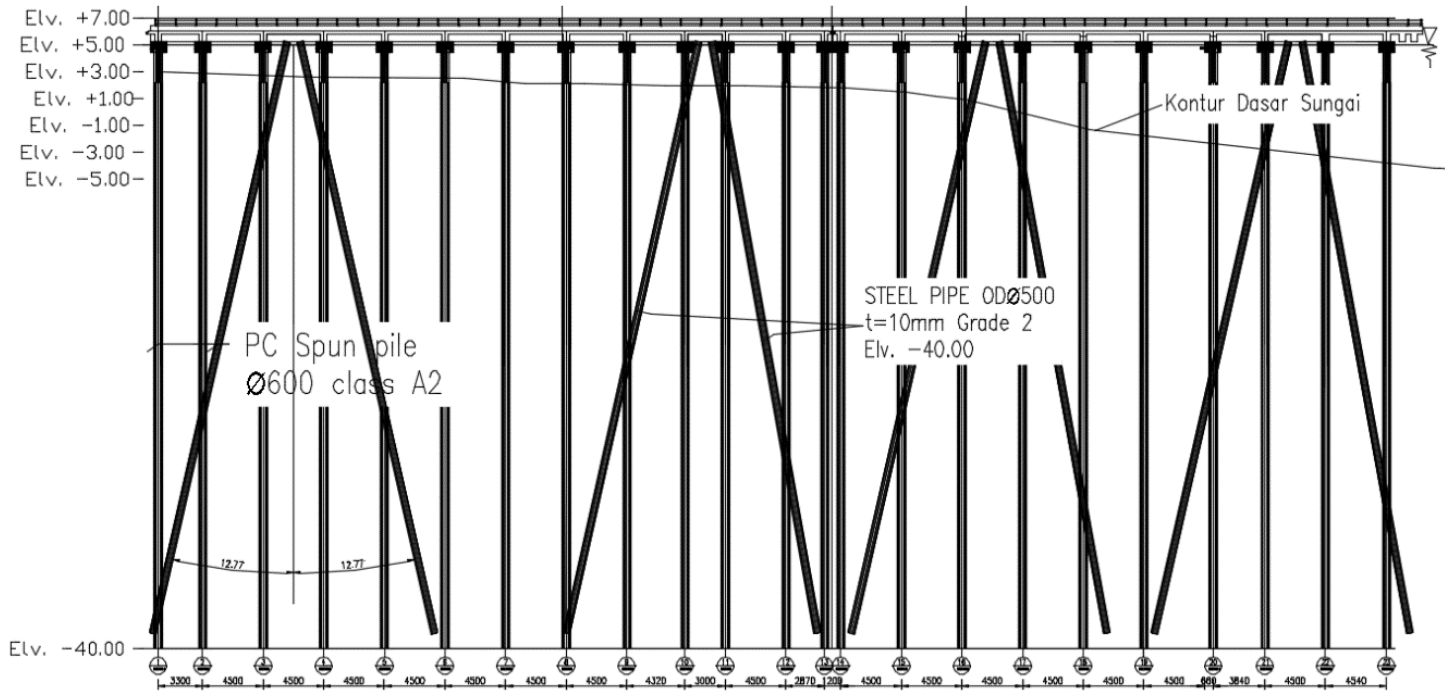

Gambar 5. Potongan Memanjang Pemasangan Batter Piles Pada Jembatan Dermaga

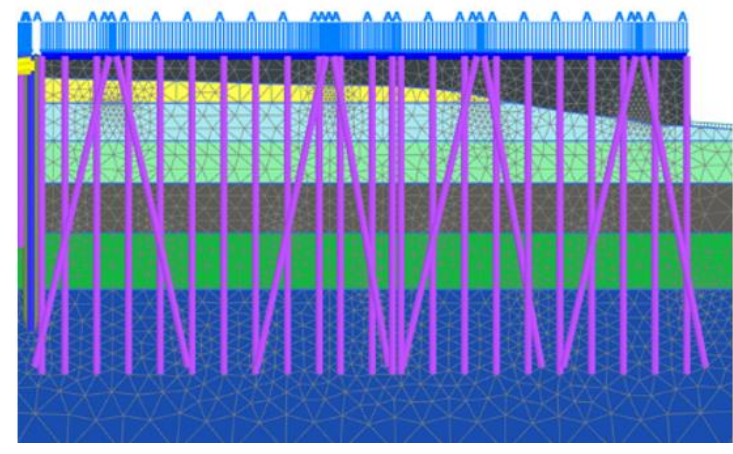

(a)

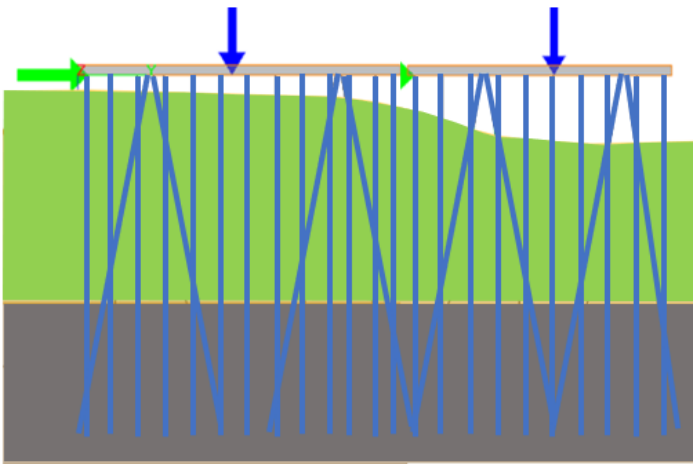

(b)

Gambar 6. Pemodelan (a) PLAXIS 2D dan (b) GROUP7 Untuk Analisis Perancangan Perkuatan dengan Batter Piles. 


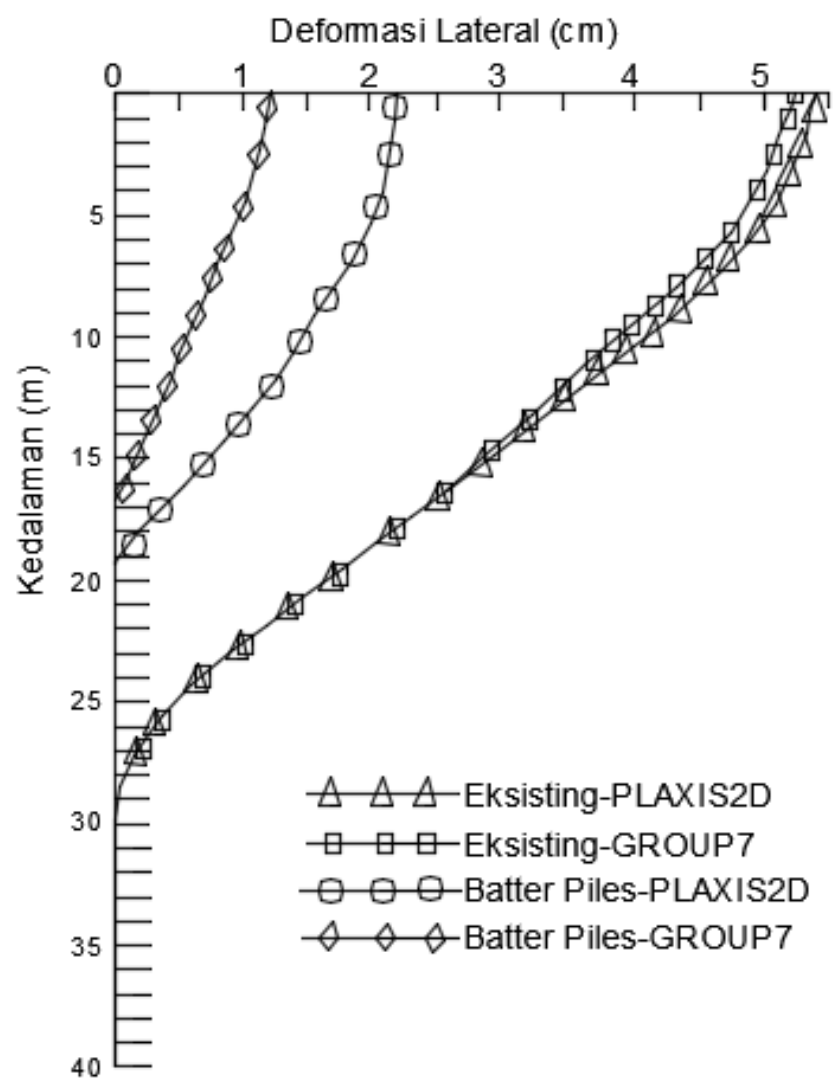

Gambar 7. Hasil Analisis Deformasi Lateral

Gambar 7 menunjukan hasil analisis deformasi lateral menggunakan perangkat lunak PLAXIS 2D dan GROUP7 yang terjadi pada jembatan dermaga untuk kondisi eksisting dan kondisi dengan menggunakan perkuatan batter piles.

\section{Hasil Analisis Jembatan Dermaga Eksisting}

Analisis deformasi lateral jembatan eksisting pada PLAXIS 2D memberikan hasil yang cukup mendekati data pengukuran, yaitu sebesar 5.40 $\mathrm{cm}$ dibandingkan dengan data pengukuran yaitu sebesar $5.10 \mathrm{~cm}$. Hal ini menunjukkan model analisis yang dibuat cukup merepresentasikan kondisi aktual jembatan eksisting. Dalam pemodelan ini konstruksi dilakukan secara bersamaan tanpa langkah konstruksi bertahap, hal ini dilakukan karena pengukuran pada jembatan dilakukan setelah konstruksi selesai, sehingga hasil deformasi lateral yang diperoleh dari analisis PLAXIS 2D relevan dengan data pengukuran yang diperoleh. Selain memberikan hasil deformasi lateral, PLAXIS 2D juga memberikan hasil berupa angka keamanan dengan nilai 1.27 , nilai ini menunjukkan bahwa tanah berada dalam kondisi stabil, akan tetapi hal ini perlu diperhatikan karena deformasi lateral yang diperoleh cukup besar. Pondasi harus dipasang mencapai kedalaman tanah keras, sehingga beban jembatan bisa disalurkan dengan baik sampai kedalaman tanah keras. Analisis pada perangkat lunak GROUP7 memberikan hasil deformasi lateral sebesar $5.27 \mathrm{~cm}$, jika dibandingkan dengan hasil analisis pada PLAXIS 2D maka GROUP7 menunjukan hasil perhitungan yang lebih mendekati kondisi pengukuran di lapangan. Pemodelan menggunakan GROUP7 dinilai cukup baik dan bisa merepresentasikan kondisi jembatan dermaga eksisting.

Dari hasil analisis yang diperoleh menggunakan PLAXIS 2D dan GROUP7, tidak terdapat kerusakan pada struktur jembatan dermaga eksisting, hal ini didasarkan pada hasil momen yang diperoleh pada analisis adalah $115.83 \mathrm{kN}-\mathrm{m}$ pada PLAXIS 2D dan $91.84 \mathrm{kN}-\mathrm{m}$ pada GROUP7, nilai ini masih berada dibawah crack moment untuk PC Spun Pile D600 Class A2, yaitu $186.33 \mathrm{kN}-\mathrm{m}$. Oleh karena itu deformasi lateral yang terjadi pada jembatan terjadi karena tanahan lateral pondasi yang tidak mencukupi, sehingga perlu dilakukan 
penambahan batter pile untuk meningkatkan daya dukung lateral tersebut.

\section{Hasil Perancangan Perkuatan Batter Piles}

Perancangan perkuatan menggunakan batter piles pada jembatan dermaga memberikan hasil yang signifikan terhadap pengurangan deformasi yang terjadi. Pada analisis menggunakan PLAXIS 2D diperoleh deformasi lateral sebesar $2.21 \mathrm{~cm}$, dimana terdapat pengurangan deformasi lateral sebesar $2.89 \mathrm{~cm}$ atau $57 \%$ dihitung terhadap deformasi hasil pegukuran. Sedangkan berdasarkan hasil analisis menggunakan GROUP7 diperoleh deformasi lateral sebesar $1.22 \mathrm{~cm}$, dimana terjadi pengurangan sebesar $3.88 \mathrm{~cm}$ atau persentase pengurangan deformasi yang terjadi adalah $76 \%$ terhadap deformasi hasil pengukuran. Dari hasil analisis pemodelan tersebut dapat dilihat bahwa penggunaan batter piles cukup efektif mengurangi deformasi lateral yang terjadi pada jembatan, hal ini terlihat dari persentase pengurangan deformasi yang diperoleh. Pemasangan batter piles menahan gaya lateral pada struktur dengan baik, karena geometri pemasangan pondasi secara miring membuat gaya lateral pada pondasi dapat terdistribusi dalam arah vertikal dan horizontal, penggunaan batter piles juga memberikan tambahan kekakuan struktur secara keseluruhan, sehingga deformasi yang terjadi menjadi relatif lebih kecil dibandingkan dengan kondisi jembatan tanpa batter piles.

Penggunaan batter piles juga memberikan angka stabilitas geoteknik yang lebih baik, dimana berdasarkan hasil analisis PLAXIS 2D diperoleh angka keamanan sebesar 2.26, dimana nilai ini meningkat cukup besar dibandingkan terhadap angka keamanan tanpa menggunakan batter piles yaitu 1.27, hal ini disebabkan oleh adanya perkuatan tambahan yang diperoleh dari pemasangan batter piles yang dipasang sampai dengan kedalaman tanah keras. Analisis deformasi lateral pada jembatan hanya merupakan salah satu dari beberapa parameter kriteria layan suatu jembatan. Oleh karena itu dalam membuat perencanaan jembatan perlu diperhatikan kriteria layan lainnya sehingga struktur memenuhi kriteria keamanan yang disyaratkan.

\section{SIMPULAN}

Analisis deformasi lateral grup pondasi tiang dengan menggunakan batter piles pada jembatan dermaga dilakukan menggunakan perangkat lunak PLAXIS 2D dan GROUP7, pemodelan dilakukan terhadap jembatan dengan kondisi eksisting (tanpa perkuatan batter piles) dan jembatan dengan kondisi menggunakan perkuatan batter piles. Dari analisis yang dilakukan diperoleh kesimpulan sebagai berikut:

1. Pemodelan kondisi jembatan eksisting tanpa menggunakan perkuatan batter piles dapat dianalisis dengan baik menggunakan perangkat lunak PLAXIS 2D dan GROUP 7, hal ini terlihat dari hasil analisis yang diperoleh cukup mendekati hasil pengukuran. Penggunaan perangkat lunak sebagai alat bantu dalam melakukan perhitungan memberikan kemudahan dalam proses pekerjaan dan mampu mempersingkat waktu perhitungan, akan tetapi proses pengerjaan oleh pengguna merupakan hal yang sangat penting untuk diperhatikan.

2. Penggunaan batter piles pada pondasi jembatan mampu mengurangi deformasi lateral yang terjadi. Pengurangan deformasi lateral yang terjadi disebabkan oleh peningkatan tahanan lateral pondasi yang diperoleh dari kemiringan pemasangan batter piles, gaya lateral yang tejadi didistribusikan dalam arah aksial dan lateral pada batter piles.

3. Batter piles meningkatkan stabilitas geoteknik dan struktur, hal ini disebabkan oleh peningkatan daya dukung pondasi dan penambahan kekakuan struktur. Untuk memastikan keamanan pada jembatan, selain dilakukan pengukuran deformasi lateral, perlu dilakukan pengecekan struktur secara langsung, diantaranya pengecekan integritas tiang, pengecekan retak pada struktur beton, dan pengecekan struktur lainnya yang bertujuan untuk memastikan kondisi jembatan dalam kondisi baik.

\section{DAFTAR PUSTAKA}

Ashour, M., Alaaeldin, A. \& Arab, M., 2019. Laterally Loaded Battered Piles in Sandy Soils. Journal of Geotechnical and Geoenvironmental Engineering 146(1).

Brinkgreve, R., 2015. Plaxis Material Models Manual, Delf, Netherlands. p. 16p.

Chen, C. \& Hsu, H., 2017. Modeling of Batter Pile Behavior under Lateral Soil Movement. IOP Conference Series: Materials Science and Engineering, p. 216.

Han, K., Seo, M. J., Hong, W. T. \& Lee, J. S., 2021. End-Bearing Capacity of Embedded 
Piles with Inclined-Base Plate: Laboratory Model Tests. Journal of Geotechnical and Geoenvironmental Engineering, Volume 146. Isenhower, W. \& Wang, S., 2014. User's Manual for LPILE 2013: A Program to Analyze Deep Foundations Under Lateral Loading, ENSOFT. Austin, TX. p. 177p.

Matlock, H., 1970. Correlation for Design of Laterally Loaded Piles in Soft Clay. Pro. 2nd Offshore Tech. Conf., Houston, Vol 1.

Shahrour, I., A, H. \& S, M., 2012. 3D elastoplastic analysis of the seismic performance of Inclined Micropile. Soil Dynamics and Earthquake Engineering , Volume 42, pp. 275-29.

Sullivan, W., Reese, L. \& Fenske, P., 1980. Unified method for analysis of laterally loaded piles in clay. Numerical methods in offshore piling, pp. 135-146.

Willson, K. et al., 2006. LRFD for Highway Bridge Substructures and Earth Retaining Structures. FHWA-NHI-05-094. U.S. Dept. of Transportation, Federal Highway Administration, p. 1730p.

Xie, Y. et al., 2017. Lateral load bearing capacity of offshore high-piled wharf with batter piles. Ocean Engineering, pp. 377-387.

Zhe, Z. Q. \& Dong, Z. W., 2014. Numerical Analysis of the Mechanical Properties of Batter Piles under Inclined Loads. Journal of Highway and Transportation Research and Development , 8(2). 